\title{
CHANGES IN WEED INFESTATION OF COMMON BEAN (Phaseolus vulgaris L.) UNDER CONDITIONS OF STRIP INTERCROPPING AND DIFFERENT WEED CONTROL METHODS
}

\author{
Aleksandra Głowacka \\ University of Life Sciences in Lublin, Faculty of Agricultural Sciences in Zamość, Szczebrzeska 102, 22-400 Zamość, Poland \\ e-mail: aleksandra.glowacka@up.lublin.pl
}

Received: 19.02.2010

\section{Abstract}

The experiment was conducted in the years 2004-2006 in a private farm in the village of Frankamionka in Zamość district. There were two experimental factors: I. Cultivation methods - sole cropping and strip intercropping; and II. Tending methods - mechanical, mechanical-chemical, and chemical weed control. The subject of the study was weed infestation of the Mela variety of common bean. Beans were sown between 30 April and 5 May. Weed infestation was assessed in the last week before harvesting by determining its floristic composition and the frequency of occurrence of particular weed species, as well as the air-dry weight of weeds.

The dominant weed species were Galinsoga parviflora, Echinochloa crus-galli, Chenopodium album, and Amaranthus retroflexus, which comprised $84.7 \%$ of the total number of weeds. Strip intercropping markedly reduced the number of weeds per unit area (by 50\%), as well as the dry weight of their aerial parts. The most effective method of weed control was the mechanical-chemical method, which resulted in the lowest occurrence of weeds. It also significantly reduced the weight of weeds.

Key words: strip cropping, weed infestation, tending, bentazon, trifluralin, quizalofop-p-butyl

\section{INTRODUCTION}

Common bean belongs to plants sensitive to weed competition. To avoid yield decrease, common bean crop should be kept weed-free 3 to 5 weeks after sowing (Dobrzański, 1996; Chmielowiec and B o r o w y, 1998). When weeds accompany common bean during the entire growing-season, seed yield can be reduced even about $60 \%$ ( $\mathrm{He} \mathrm{m} \mathrm{s} \mathrm{s,} \mathrm{1985).}$ Herbicide application is the main method used in weed control. But in recent years there has been a trend to decrease the quantity of applied herbicides, and to minimize their negative influence on the environment. One of the ways to achieve this goal is intercropping that has been used for fodder and food production for many years in various parts of the world ( $\mathrm{Carruthers}$ et al. 1998). This system results in more stable yields, and due to the more efficient use of nutrients, water, and light, it is possible to limit expenditures [Horwith, 1985; Fukai and Tren bath, 1993; Z a n g and Li , 2003]. Strip intercropping attempts to reconcile the interests of the farmer and protection of the environment. It is a form of mixed cropping in which two or more crops are grown side by side in strips wide enough to enable independent mechanical cultivation, but sufficiently narrow to allow interaction of ecological factors. Because strip intercropping involves more species, it is similar to a natural ecosystem, and the spatial diversity can lead to increased total yield. Diseases, particularly those associated with weather conditions, have less effect on yield. Competition from pests and weeds is also reduced, so that the use of pesticides can be restricted (C r u s o e, 1990; L i e b m a n and D y ck, 1993). The Polish literature contains numerous studies on the advantages of mixed cropping (Le s z c z y ń s k a and C a c a k - P i e trzak, 2006; Buczek et al. 2007; Sadowski et al. 2003), but none have examined how strip intercropping influenced weed infestation and how it can be used in Polish agriculture.

The aim of the study was to assess how different cultivation and tending methods affect weed infestation of the common bean crop.

\section{METHODS AND CONDITIONS}

A field experiment was conducted in an private farm in the village of Frankamionka in Zamość district in the years 2004-2006. The experiment was set up in a split-plot design with four replications. The experi- 
mental field was located on soil of clayey silt granulometric composition, slightly acidic $(\mathrm{pH}$ in $1 \mathrm{n} \mathrm{KCl}$ -6.5 ), containing $1.9 \%$ of organic matter.

The subject of the study was weed infestation of the Mela cultivar of common bean (Phaseolus vulgaris L.). This is a very early, high-yielding variety, cultivated for dry seeds, suitable for growing all over Poland (except for a few northern regions).

The following factors were analysed in the experiment:

I. Cultivation methods

a. sole cropping, in which the size of one plot was $23.75 \mathrm{~m}^{2}$ for sowing and $17 \mathrm{~m}^{2}$ for harvesting.

b. strip intercropping, in which three crops - dent maize (Zea mays L. ssp. indentata) 'Veritis', common bean, and spring wheat (Triticum aestivum ssp. vulgare L.) 'Helia', were grown side by side, each in separate strips $2.5 \mathrm{~m}$ wide. The distance between the maize and common bean strips was $50 \mathrm{~cm}$, and between common bean and spring wheat was $30 \mathrm{~cm}$. The size of one common bean plot was $11.75 \mathrm{~m}^{2}$ for sowing and $10.5 \mathrm{~m}^{2}$ for harvesting.

II. Tending methods

A - mechanical (weeding of inter-rows twice, the first time four-five weeks after sowing and the second time three weeks later)

B - mechanical-chemical; the herbicide Treflan $480 \mathrm{EC}$ (trifluralin), before sowing at $1.51 \mathrm{~L}$ $\times$ ha $^{-1}$ with $300 \mathrm{~L} \times$ ha $^{-1}$ water + weeding of inter-rows once (at the same times as the second weeding of inter-rows in the mechanical treatment)

C - chemical; the herbicide Treflan 480 EC (trifluralin) before sowing at $1.5 \mathrm{~L} \times$ ha $^{-1}$ with 300 $\mathrm{L} \times \mathrm{ha}^{-1}$ water, Basagran $600 \mathrm{SL}$ (bentazon), post-emergence at $2 \mathrm{~L} \times$ ha $^{-1}$ with $200 \mathrm{~L} \times$ ha $^{-1}$ water, and Targa Super 05 EC (quizalofop-Pethyl) post-emergence at $1 \mathrm{~L} \times \mathrm{ha}^{-1}$ with 200 $\mathrm{L} \times \mathrm{ha}^{-1}$ water.

Trifluralin was applied half a day before common bean sowing, and it was mixed with soil 6-8 cm deep immediately after application. Bentazon was used four weeks after sowing, when the common bean plants were at the first triple-leaf stage and the majority of dicotyledonous weeds were at the 4-leaf stage. Quizalofop-P-ethyl was applied five weeks after sowing, when the majority of weeds were at the second leaf stage - before the tillering stage. The herbicides were applied by a 'Pilmet Sano 2 P-030' backpack sprayer.

Beans were sown between 30 April and 5 May, at $45 \mathrm{~cm}$ row spacing using a one-row hand seeder. The planting density of common bean was 45,000 plants per hectare. Spring wheat was sown between 15 and 20 April in a quantity of $220 \mathrm{~kg}$ of seeds per hectare, dent maize was sown at the same time as common bean and the planting density was 120,000 plants per hectare. In the case of the two accompanying plants, three different tending methods were also applied (mechanical, mechanical-chemical, and chemical weed control).

Fertilization for common bean was applied uniformly in the amounts of $\mathrm{N}-30 \mathrm{~kg} \times \mathrm{ha}^{-1}, \mathrm{P}-40 \mathrm{~kg}$ $\times \mathrm{ha}^{-1}$ and $\mathrm{K}-108 \mathrm{~kg} \times \mathrm{ha}^{-1}$ (in the following form: $\mathrm{N}$ - ammonium nitrate, $\mathrm{P}$ - super-phosphate, $\mathrm{K}$ - potassium sulphate). All the fertilizers were applied once before sowing. Tillage was conducted by the traditional method according to the recommendations for this plant.

Weed infestation of the common bean crop was assessed in the last week before harvesting by determining species composition and frequency as well as the dry weight of weeds. On each plot, two random sample areas were set off with a $1 \mathrm{~m} \times 0.5 \mathrm{~m}$ frame. Within each frame, individual weed plants were counted and floristic composition was determined. When the weeds had been extracted and their roots cut off, the plants were dried and then weighed to determine their air-dry weight. Species nomenclature followed M i r e k et al. (2002). Common bean was harvested by hand in late August or early September. The results were analysed statistically using variance analysis. Differences between means were evaluated with Tukey's test. The results were tested at a $95 \%$ probability.

\section{RESULTS}

The analysed experimental factors significantly influenced the weed infestation of the common bean crop. A total of 21 species of weeds were noted, of which 16 were ephemeral and 5 were perennial (Tables 1 and 2). Only 3 of the 21 species were monocotyledonous. These were barnyard grass (Echinochloa crus-galli), which occurred in high numbers in all the combinations, and - occurring sporadically - yellow foxtail (Setaria glauca) and loose silky-bent (Apera spica-venti). Most of the species (18) were dicotyledons. The number of weed species was not affected by the cropping method. Despite the small number of monocotyledonous species, these comprised $30 \%$ and $14.9 \%$ of the total number of weeds in the sole cropping and intercropping, respectively (Fig. 1). The tending methods, on the other hand, significantly influenced the species biodiversity of the weeds. The greatest number of species was noted where chemical tending was applied, and the fewest when tending was limited to mechanical weeding of the inter-rows (twice). The proportion of monocotyledons was also influenced by the different methods of weed control (Table 5). In the treatments in which the chemical methods were used, the number of barnyardgrass weeds was greater 
Table 1

Species composition and number of weeds per $1 \mathrm{~m}^{2}$ growing in the common bean crop before harvest, depending on the cropping system (mean for 2004-2006)

\begin{tabular}{|c|c|c|}
\hline \multirow{2}{*}{ Species composition } & \multicolumn{2}{|c|}{ Cropping system } \\
\hline & Sole cropping & Strip cropping \\
\hline \multicolumn{3}{|c|}{ Short-lived } \\
\hline Galinsoga parviflora Cav. & 27.4 & 11.5 \\
\hline Echinochloa crus-galli (L) P. Beauv & 13.2 & 3.0 \\
\hline Chenopodium album $\mathrm{L}$ & 5.2 & 2.0 \\
\hline Amaranthus retroflexus $\mathrm{L}$. & 5.4 & 3.0 \\
\hline Solanum nigrum $\mathrm{L}$. & 0.5 & 0.3 \\
\hline Galium aparine $\mathrm{L}$. & 0.5 & - \\
\hline Polygonum nodosum $\mathrm{L}$. & 0.8 & 1.5 \\
\hline Capsella bursa-pastoris (L.) Medik. & 0.9 & 1.2 \\
\hline Matricaria maritima subsp. inodora (L.) Dostal & 0.5 & 0.3 \\
\hline Setaria pumila (Poir) Roem. \& Schulz. & - & 0.1 \\
\hline Stelaria media $\mathrm{L}$. & 0.1 & 0.1 \\
\hline Euphorbia helioscopia L. & 0.4 & 0.6 \\
\hline Thlaspi arvense $\mathrm{L}$. & 0.1 & 0.2 \\
\hline Apera spica venti (L.) P. Beauv. & - & 0.1 \\
\hline Galeopsis tetrahit $\mathrm{L}$. & 0.3 & 0.1 \\
\hline Sonchus asper L. & 0.1 & - \\
\hline Total of short-lived weeds & 55.4 & 24.0 \\
\hline Number of short-lived species & 14 & 14 \\
\hline \multicolumn{3}{|l|}{ Perennial } \\
\hline Convolvulus arvensis L. & 0.1 & 0.1 \\
\hline Taraxacum officinale Web. & 0.7 & 0.2 \\
\hline Equisetum arvense $\mathrm{L}$. & 0.6 & - \\
\hline Plantago maior $\mathrm{L}$. & 0.7 & - \\
\hline Trifolium pretense $\mathrm{L}$. & - & 0.1 \\
\hline Total of perennial weeds & 2.7 & 0.4 \\
\hline Number of perennial species & 4 & 3 \\
\hline Total number of species & 18 & 17 \\
\hline
\end{tabular}


Table 2

Species composition and number of weeds per $1 \mathrm{~m}^{2}$ growing in the common bean crop before harvest, depending on the tending method (mean for 2004-2006)

\begin{tabular}{|c|c|c|c|c|}
\hline \multirow{2}{*}{ Species composition } & & \multicolumn{3}{|c|}{ Tending method } \\
\hline & & $A^{*}$ & $\mathrm{~B}$ & $\mathrm{C}$ \\
\hline \multicolumn{5}{|c|}{ Short-lived } \\
\hline Galinsoga parviflora Cav. & & 21.9 & 26.7 & 9.7 \\
\hline Echinochloa crus-galli (L) P. Beauv & & 6.2 & 0.7 & 7.9 \\
\hline Chenopodium album $\mathrm{L}$ & & 8.2 & 0.9 & 1.8 \\
\hline Amaranthus retroflexus $\mathrm{L}$. & & 9.7 & 2.1 & 0.8 \\
\hline Solanum nigrum $\mathrm{L}$. & & 0.9 & - & 0.3 \\
\hline Galium aparine $\mathrm{L}$. & & 0.4 & 0.2 & 0.2 \\
\hline Polygonum nodosum L. & & 1.8 & 0.8 & 0.8 \\
\hline Capsella bursa-pastoris (L.) Medik. & & - & 0.6 & 2.5 \\
\hline Matricaria maritima subsp. inodora Dostal (L.) & & - & 0.6 & 0.5 \\
\hline Setaria pumila (Poir) Roem. \& Schulz. & & - & - & 0.1 \\
\hline Stellaria media $\mathrm{L}$. & & - & - & 0.3 \\
\hline Euphorbia helioscopia L. & & 0.4 & 0.1 & 1.1 \\
\hline Thlaspi arvense $\mathrm{L}$. & & - & 0.1 & 0.3 \\
\hline Apera spica venti (L.) P. Beauv. & & - & - & 0.1 \\
\hline Galeopsis tetrahit $\mathrm{L}$. & & - & - & 0.5 \\
\hline Sonchus asper L. & & 0.2 & - & - \\
\hline Total of short-lived weeds & & 49.7 & 32.8 & 26.9 \\
\hline Number of short-lived species & & 9 & 10 & 15 \\
\hline \multicolumn{5}{|c|}{ Perennial } \\
\hline Convolvulus arvensis $\mathrm{L}$. & & - & 0.2 & - \\
\hline Taraxacum officinale Web. & & - & 0.3 & 0.1 \\
\hline Equisetum arvense L. & & - & 0.5 & 0.4 \\
\hline Plantago maior L. & & - & - & 0.3 \\
\hline Trifolium pretense L. & & - & - & 0.2 \\
\hline Total of perennial weeds & & - & 1.0 & 1.0 \\
\hline Number of perennial species & & 0 & 3 & 4 \\
\hline Total number of species & & 9 & 13 & 19 \\
\hline
\end{tabular}

*Method of tending: A - mechanical, B - mechanical-chemical, C- chemical 
Table 3

Weed density in the common bean crop $\left(\right.$ no $\left.\times \mathrm{m}^{-2}\right)$

\begin{tabular}{lccc}
\hline \multirow{2}{*}{ Tending } & \multicolumn{2}{c}{ Cropping system } & Mean \\
\cline { 2 - 4 } & Sole cropping & Strip cropping & 49.9 \\
A* & 67.9 & 31.9 & 32.4 \\
B & 46.7 & 18.6 & 46.3 \\
\hline Mean & 71.6 & 21.1 & - \\
\hline & 61.1 & 23.7 & \\
\hline \multirow{2}{*}{ LSD $_{0.05}$ for: cropping -11.3 ; tending -17.4 ; interaction -31.8} & \\
\hline
\end{tabular}

*Method of tending: A - mechanical, B - mechanical-chemical, C - chemical

Table 4

Air-dry weight of weeds in the common bean crop $\left(\mathrm{g} \times \mathrm{m}^{-2}\right)$

\begin{tabular}{lccc}
\hline \multirow{2}{*}{ Tending } & \multicolumn{2}{c}{ Cropping system } & \multirow{2}{*}{ Mean } \\
\cline { 2 - 4 } & Sole cropping & Strip cropping & 178.0 \\
*A & 206.1 & 149.9 & 110.7 \\
$\mathrm{~B}$ & 130.4 & 91.0 & 119.2 \\
\hline Mean & 134.5 & 103.9 & - \\
\hline \multicolumn{4}{l}{} \\
\cline { 2 - 3 } & 157.0 & 114.9 & \\
\hline
\end{tabular}

*Method of weed control: A - mechanical, B - mechanical-chemical, C - chemical

Table 5

Number of mono- and dicotyledonous weeds for different methods of cropping and weed control (per $1 \mathrm{~m}^{2}$ ).

\begin{tabular}{lccccc}
\hline \multirow{2}{*}{ Weeds } & \multicolumn{2}{c}{ Methods of cropping } & \multicolumn{3}{c}{ Methods of weed control } \\
\cline { 2 - 6 } & Sole cropping & Strop cropping & A* & B & C \\
\hline monocotyledonous & 13.2 & 3.2 & 6.2 & 0.7 & 8.0 \\
\hline dicotyledonous & 43.8 & 21.4 & 43.5 & 33.1 & 20.0 \\
\hline
\end{tabular}

*Method of weed control: A - mechanical, B - mechanical-chemical, C - chemical

Table 6

Yield of common bean seeds $\left(\mathrm{dt} \times \mathrm{ha}^{-1}\right)$

\begin{tabular}{lccc}
\hline \multirow{2}{*}{ Tending } & \multicolumn{2}{c}{ Cropping system } & Mean \\
\cline { 2 - 3 } & Sole cropping & Strip cropping & 10.4 \\
\hline *A & 9.3 & 11.4 & 16.9 \\
B & 16.8 & 17.1 & 18.0 \\
C & 18.1 & 18.0 & \\
\hline Mean & 14.7 & 15.5 & \\
\hline \multicolumn{2}{c}{ LSD $_{0.05}$ for: cropping $-0.38 ;$ tending -0.59 ; interaction -1.0} \\
\hline
\end{tabular}

*Method of weed control: A - mechanical, B - mechanical-chemical, C - chemical 
than in the other treatments. Irrespective of the experimental factors, the species found in the largest numbers were Galinsoga parviflora, Chenopodium album, Amaranthus retroflexus, and Echinochloa crus-galli. These dominant species comprised from $81 \%$ of the total number of weeds in the case of the intercropping to $92 \%$ in the sole cropping. The remaining species occurred rarely or sporadically.

Under the conditions of strip cropping of beans with dent maize and spring wheat, the total number of weeds per unit area was significantly lower; weed density was over $50 \%$ lower than in the case of the sole cropping (Table 3). This indicator was also influenced by the weeding method. Significant differences were noted between mechanical tending and mechanical-chemical tending. Like the number of weeds, the weight of their aerial parts was also significantly lower in the case of the strip intercropping. The tending method also had a very marked influence. The highest dry weight of aerial parts was noted in the case of mechanical weeding, while significantly lower weights were produced by the weeds when one of the other tending methods was applied. The differences between the mechanical-chemical method and the chemical method were small and statistically insignificant (Table 4).

Changes in weed infestation of common bean, as a result of different cultivation and tending methods, influenced the yield of seeds. Strip cropping significantly increased yield as compared to sole cropping. The highest weed infestation under the conditions of the mechanical method resulted in a low yield of common bean. The other tested methods of tending significantly increased seed yields (Table 6).

\section{DISCUSSION}

The dominant species in weed infestation of the common bean crop were Galinsoga parviflora, Echinochloa crus-galli, Chenopodium album, and Amaranthus retroflexus. These species are also mentioned by Ch mielowie c and B orow y (2004) as those occurring most frequently in bean crops in the Lublin region. They accounted for $84.7 \%$ of the total number of weeds. The most frequently occurring species was Galinsoga parviflora (47\%). The remaining species occurred sporadically.

Pulse crops grow slowly in the initial phase, which creates favourable conditions for the development of weeds. Mechanical methods of weed control are not always effective, especially in unfavourable weather conditions. In the present study, the highest weed infestation was found to result when mechanical procedures alone were used for weed control. The most effective was the mechanical-chemical method, which significantly reduced both the number of weeds and their dry weight. This method is gaining in importance due to the promotion of integrated agriculture and efforts to restrict the use of chemicals (Podleśny, 2007). The chemical method was less effective in reducing the number of weeds per unit area. This could be due to the high frequency of barnyardgrass, which is resistant to bentazon, and of Galinsoga parviflora, which emerged after the active substance in the herbicide was no longer effective. Survived plants of Echinochloa crus-galli could have been covered by bean leaves or were at a later stage of growth and this decreased the effect of quizalofop-P-ethyl application. Chmielowiec and B orowy (2004) report that after the application of bentazon survived weeds were most advanced in growth and with leafs covered by little hairs (Amaranthus retroflexus, Galinsoga ciliata) and they were also shaded by bean leaves.

Mixed cropping increases genetic diversity, thereby improving the health and production capacity of crops (Les zczyńs ka and Cacak-Pie$\operatorname{trzak}, 2006)$. Numerous studies also confirm the beneficial influence of mixed cropping in reducing weed infestation, as compared with monoculture (I d z i k and M ichals ki, 2003; S a d ow ski et al. 2003; B u c zek et al. 2007). Strip intercropping, which is a form of mixed cropping, reduces the threat posed by pests and weeds, so that pesticide use can be restricted (C a r ruthers et al. 1998; G ł ow a c ka, 2007). This is confirmed by the results of the present study. Strip intercropping of common bean with dent maize and spring wheat led to a substantial, statistically significant reduction in both the density of weeds in the bean field and their dry weight, as compared with the sole cropping. It is worth emphasizing that in the case of strip intercropping with solely mechanical tending the values of these weed infestation indicators were similar to those obtained for sole cropping with mechanical-chemical tending. This indicates that strip intercropping can be applied in agriculture that is sustainable, integrated and even organic - after herbicides have been eliminated ( $\mathrm{G}$ ł o w a c k a, 2007).

\section{CONCLUSIONS}

1. In the segetal community of the common bean, 21 species were noted, of which 16 were ephemeral and 5 perennial. The ephemeral species of Galinsoga parviflora, Echinochloa crus-galli, Chenopodium album, and Amaranthus retroflexus were dominant weeds. Perennial species occurred sporadically.

2. Strip intercropping significantly reduced the occurrence of weeds in the common bean crop. Both the number of weeds and their dry weight were almost $50 \%$ lower under strip intercropping conditions than in sole cropping. 
3. The least effective weed control method was the mechanical method. The most beneficial method for reducing weed infestation was to combine the chemical and mechanical procedures.

\section{REFERENCES}

Buczek J., Tobiasz-Salach R., Bobrecka-Jamro D., 2007. Ocena plonowania i odchwaszczającego działania jarych mieszanek zbożowych. / Assesment of yielding and weeding effects of mixed spring cereals. Zesz. Prob. Post. Nauk Rol. 516: 11-18 (in Polish).

Carruthers K. Fe. Q., Cloutier D., Smith D. L., 1998. Intercropping corn with soybean, lupine and forages: weed control by intercropping combined with inter-row cultivation. Eur. J. Agron. 8: 225-238.

Chmielowiec P., B orow y A., 1998. Wpływ konkurencji chwastów na plonowanie fasoli zwykłej (Phaseolus vulgaris L.) uprawianej na suche nasiona. / The influence of weed competition on yielding of common bean (Phaseolus vulgaris L.) grown for dry seeds. Zesz. Nauk. AR Kraków, 333: 75-80 (in Polish).

Chmielowi e c P., B or ow y A., 2004. Ocena działania bentazonu i metolachloru w uprawie fasoli zwykłej (Phaseolus vulgaris L.) 'BONA'. / Evaluation of the effect of bentazon and metolachlor in common bean (Phaseolus vulgaris L.) 'Bona' crops. Act. Sci. Pol., Hortorum Cultus, 3 (1): 75-87 (in Polish).

Crusoe R. M., 1990. Strip intercropping. Farming System for Iowa: Seeking Alternatives, Leopold Center for Sustainable Agriculture. Conference Proceedings. Iowa State University, Ames: 39-41.

D obrzańs ki A., 1996. Krytyczne okresy konkurencji chwastów a racjonalne stosowanie herbicydów w uprawie warzyw. / Critical periods of weed competition in vegetable crops in relation to rational herbicides application. Progr. Plant Protect./Post. Ochr. Rośl. 36 (1): 110-116 (in Polish).

Fukai S., Trenbath B. R., 1993. Processes determining intercrop productivity and yields of component crops. Field Crops Res. 34: 247-271.

G łow acka A., 2007. Wpływ współrzędnej uprawy pasowej na zachwaszczenie kukurydzy pastewnej. / Effect of the strip intercropping system on weed infestation in maize. Acta Agrophysica, 10 (3): 573-582 (in Polish).

H a u g g a rd-Niel s en H., A nders on M. K., Jřrn s ga ard B., J en s e n E. S., 2006. Density and relative frequency effects on competitive interactions and resource use in pea-barley intercrops. Field Crop Res. 70: 101-109.

Heem s H. D. J. van, 1985. The influence of competition on crop yield. Agric. Systems. 18: 81-93.

Horwith B., 1985. A role for intercropping in modern agriculture. BioScience, 35: 286-291.

Idziak R., Michalski T., 2003. Zachwaszczenie i plonowanie mieszanek jęczmienia jarego i owsa przy różnym udziale obu komponentów w zasiewie. / Weed infesta- tion and yields of spring barley and oat in mixtures with different shares of both species. Zesz. Prob. Post. Nauk Roln. 490: 99-104.

Leszczýnska D., Cacak-Pietrzak G., 2006. Wpływ obecności owsa (formy oplewionej i nieoplewionej) na cechy plonotwórcze jęczmienia w zasiewie mieszanym. / The effect of the presence of oat (hulled and naked form) on yielding parameters of barley in a mixed stand. Prog. in Plant Protect./Post. w Ochr. Roś. 46 (2): 19-23 (in Polish).

Liebman M., Dyck E., 1993. Crop rotation and intercropping for weed management. Ecol. App. 3: 92-122.

Mirek Z., Piękoś-Mirkowa H., Zając A., Zając M., 2002. „Flowering plants and pterdophytes of Poland. A checklist" Krytyczna lista roślin naczyniowych polski. Wyd. Inst. Botaniki im. W. Szafera PAN Kraków: 442.

Podleśny J., 2007. Główne problemy agrotechniki roślin strączkowych. / The main issues of agricultural practices used in growing leguminous crops. Wieś Jutra, 3 (104): 34-36 (in Polish).

S a dow sk i T., Kr ześl a k S., Z aw iśla k K., 2003. Wpływ płodozmianu na zachwaszczenie mieszanki zbożowej. / Influence of crop rotation on weed infestation of cereal mixture. Zesz. Prob. Post. Nauk Rol. 490: 211-217 (in Polish).

Zhang F., Li L., 2003. Using competitive and facilitative interactions in intercropping systems enhances crop productivity and nutrient-use efficiency. Plant and Soil, 248: 305-312.

\section{Zmiany w zachwaszczeniu fasoli zwyczajnej (Phaseolus vulgaris L.) w warunkach uprawy współrzędnej pasowej i różnych metod odchwaszczania}

\section{Streszczenie}

Doświadczenie przeprowadzono w latach 2004-2006 w gospodarstwie indywidualnym położonym we wsi Frankamionka powiat zamojski. Schemat badań obejmował dwa czynniki: I. Metoda uprawy - siew czysty i uprawa współrzędna pasowa, polegająca na uprawie w sąsiadujących ze sobą pasach o szerokości 2,5 m trzech roślin: kukurydzy pastewnej, fasoli zwyczajnej i pszenicy jarej; II. Metody pielęgnacji - mechaniczna (dwukrotne opielanie międzyrzędzi), mechaniczno-chemiczna (herbicy Treflan 480 EC przed siewem + jednokrotne opielanie międzyrzędzi) i chemiczna (herbicyd: Treflan 480 EC przed siewem + Basagran 600 SL i Targa Super 05 EC powschodowo). Przedmiotem badań było zachwaszczenie fasoli zwyczajnej odmiany Mela. Fasolę wysiewano pomiędzy 30 kwietnia a 5 maja. Zachwaszczenie łanu fasoli określono w ostatnim tygodniu przed zbiorem metodą botaniczno-wagową, określając skład florystyczny 
i liczebność poszczególnych gatunków chwastów oraz powietrznie suchą masę chwastów.

Gatunkami dominującymi w zachwaszczeniu fasoli zwyczajnej były Galinsoga parviflora, Echinochloa crus-galli, Chenopodium album oraz Amaranthus retroflexus, stanowiące $84,7 \%$ ogólnej liczby chwastów. Uprawa współrzędna pasowa wyraźnie zmniejszała liczbę chwastów na jednostce powierzchni (o 50\%), jak i wytworzoną przez nie sucha masę części nadziemnych. Najskuteczniejszą metodą regu- lacji zachwaszczenia była metoda mechaniczno-chemiczna. W warunkach jej stosowania stwierdzono najmniejsze nasilenie występowania chwastów. Sprzyjała ona również znacznemu ograniczeniu masy wytwarzanej przez chwasty. Korzystny wpływ uprawy pasowej na ograniczenie zachwaszczenia sprzyjał wytwarzaniu większego plonu handlowego nasion w porównaniu do siewu czystego. Najmniejszy plon nasion otrzymano przy stosowaniu mechanicznych zabiegów regulacji zachwaszczenia. 